\title{
Weed infestation of spring barley grown after different previous crop
}

\section{Zachwaszczenie jęczmienia jarego uprawianego po różnych przedplonach}

\author{
Leszek Majchrzak, Tomasz Piechota
}

\section{Summary}

A field study was carried out between the years 2008-2009 at the Research Station Swadzim that belongs to Poznań University of Life Sciences. The objective of the study was to determine the effect of tillage system and previous crop on the changes in infestation and species compositions in spring barley. As compared to the traditional tillage, direct drilling increased over $100 \%$ mass of weeds per unit area. Number of weeds was higher by $60 \%$ and more on the plots with direct drilling. There was significant influence of previous crop on number of weeds in spring barley. Number of weeds was $40 \%$ higher when spring barley was cultivated after fodder beet compared to the plots where spring barley was cultivated after maize. The dominance species were: Viola arvensis, Chenopodium album, Senecio vulgaris, Geranium pusillum, Anthemis arvensis, Matricaria maritima, Lycopsis arvensis, Brassica napus and Echinochloa crus-galli. There was no significant influence of previous crop on values of dominance index (C). Significant higher value were recorded on the treatments with spring barley cultivated with conventional tillage technology. Higher values of Shannon's biodiversity index $(\mathrm{H})$ were obtained on the treatments where spring barley was cultivated in direct drill after maize crop and also after fodder beet crop when ploughing cultivation system was applied.

Key words: weeds, spring barley, previous crop, biodiversity index, dominance index

\section{Streszczenie}

Badania przeprowadzono w latach 2008-2009, w Zakładzie Doświadczalno-Dydaktycznym Gorzyń, filia Swadzim należącym do Uniwersytetu Przyrodniczego w Poznaniu. Ich celem była ocena wpływu sposobu uprawy gleby i rodzaju przedplonu na stan i stopień zachwaszczenia jęczmienia jarego. Na obiektach z siewem bezpośrednim obserwowano ponad dwukrotny wzrost masy chwastów na jednostce powierzchni, natomiast wzrost ich liczby w stosunku do tradycyjnej uprawy płużnej wynosił ponad 60\%. Rodzaj przedplonu wpływał na liczbę chwastów w łanie jęczmienia jarego. Na obiektach, na których był on wysiewany po kukurydzy charakteryzował się o 40\% większą liczbą chwastów w odniesieniu do jego uprawy po buraku pastewnym. W zasiewach szczególnie licznie występowały takie gatunki, jak: Viola arvensis, Chenopodium album, Senecio vulgaris, Geranium pusillum, Anthemis arvensis, Matricaria maritima, Lycopsis arvensis, Brassica napus i Echinochloa crus-galli. Nie stwierdzono istotnego wpływu przedplonu na wartość wskaźnika dominacji (C). Istotnie wyższe wartości tego wskaźnika odnotowano w odniesieniu do zachwaszczenia jęczmienia uprawianego w technologii tradycyjnej. Wyższe wartości wskaźnika bioróżnorodności Shannona (H) wykazano w odniesieniu do zachwaszczenia przy uprawie jęczmienia w stanowisku po kukurydzy w technologii siewu bezpośredniego, natomiast w stanowisku po buraku pastewnym wskaźnik ten przyjmował wyższe wartości, gdy zastosowano płużną uprawę roli.

Słowa kluczowe: chwasty, jęczmień jary, przedplon, wskaźnik bioróżnorodności, wskaźnik dominacji

\author{
Uniwersytet Przyrodniczy w Poznaniu \\ Katedra Agronomii \\ Dojazd 11, 60-632 Poznań \\ leszmaj@up.poznan.pl
}




\section{Wstęp / Introduction}

Zachwaszczenie jest jednym z podstawowych czynników ograniczających plonowanie roślin. Chwasty konkurują o wszystkie składniki potrzebne do wegetacji uprawianej rośliny. Wyniki wielu badań wskazują, że modyfikacja uprawy płużnej (głównie jej uproszczenie) oprócz zmian podstawowych właściwości fizycznych, chemicznych i biologicznych gleby może powodować wzrost zachwaszczenia pól (Tørresen i wsp. 2003; Ghosheh i AlHajaj 2004). Szczególnie wzrasta zachwaszczenie chwastami wieloletnimi, a w konsekwencji następuje spadek plonowania roślin (Starczewski i Czarnocki 2004; Kraska i Pałys 2006; Małecka i wsp. 2012), które często zależne jest od przebiegu warunków pogodowych oraz siedliska i stosowanej agrotechniki (Schillinger i wsp. 1999).

Celem przeprowadzonych badań była ocena stanu i stopnia zachwaszczenia jęczmienia jarego w zależności od sposobu uprawy gleby i rodzaju przedplonu.

\section{Materiały i metody / Materials and methods}

Badania polowe w układzie bloków losowanych, w czterech powtórzeniach prowadzono w Zakładzie Doświadczalno-Dydaktycznym Gorzyń, filia Swadzim należącym do Uniwersytetu Przyrodniczego w Poznaniu. Eksperyment zlokalizowano na glebie płowej o składzie granulometrycznym piasku gliniastego lekkiego płytko zalegającym na glebie lekkiej. Zaliczano ją do klasy bonitacyjnej IVb kompleksu żytniego bardzo dobrego. Gleba wykazywała odczyn obojętny (pH w 1 mol $\mathrm{KCl}=7,17)$. Charakteryzowała się wysoką zasobnością w fosfor (161,8 mg P/kg gleby) i w potas $(281,7 \mathrm{mg} \mathrm{K} / \mathrm{kg}$ ) oraz magnez $(59 \mathrm{mg} \mathrm{Mg} / \mathrm{kg}$ ). Zawartość węgla organicznego mieściła się w przedziale $0,79-1,07 \%$.

Jęczmień jary odmiany Stratus wysiewano w pierwszej dekadzie kwietnia (w ilości $170 \mathrm{~kg} / \mathrm{ha}$ ) na poletkach doświadczalnych o powierzchni $30 \mathrm{~m}^{2}$. Zarówno w roku 2008, jak i 2009 uprawiano go w stanowisku po kukurydzy i buraku pastewnym $w$ dwóch systemach uprawy roli: tradycyjnym i siewie bezpośrednim. Na wszystkich obiektach doświadczenia na początku fazy krzewienia (BBCH 22) stosowano herbicydy Chwastox Turbo 340 SL (MCPA + dikamba) w dawce 2,0 1/ha + Puma Uniwersal 069 EW (fenoksaprop-P-etylowy + mefenpyr dimetylowy) w dawce 1,2 1/ha. Na początku wzrostu źdźbła (BBCH 30) na całości doświadczenia zastosowano fungicyd Alert 375 SC (flusilazol + karbendazym) w dawce 1,0 1/ha. Na wszystkich obiektach doświadczenia w fazie 2 kolanka (BBCH 32) stosowano antywylegacz Cerone 480 SL (etefon) w dawce 1,0 1/ha.

Liczebność i skład gatunkowy chwastów oznaczano corocznie przed zastosowaniem herbicydów metodą botaniczno-wagową w fazie krzewienia jęczmienia (BBCH 21-22). Chwasty do analizy pobierano $\mathrm{z}$ powierzchni $1 \mathrm{~m}^{2}$ (dwa rzuty ramką o wymiarach $1 \times 0,5 \mathrm{~m} \mathrm{w}$ wybranych losowo punktach każdego poletka). Wyniki uzyskane z poszczególnych powtórzeń uśredniono i podano wartości dla poszczególnych kombinacji badawczych.
Obliczono również wskaźniki zachwaszczenia (Topham i Lawson 1982):

Wskaźnik relatywnej obfitości - Ra

$$
\mathrm{Ra}=\frac{\mathrm{rd}+\mathrm{rf}}{2}
$$

Ra - wskaźnik relatywnej obfitości (relative abundance index),

rd - względna gęstość gatunku na $\mathrm{m}^{2}$ będąca ilorazem liczby osobników danego gatunku i liczby osobników wszystkich gatunków na powierzchniach próbnych obiektu,

rf - względna częstość występowania gatunku na powierzchniach próbnych, czyli liczba wystapień gatunku w stosunku do liczby wystapień wszystkich gatunków na powierzchniach próbnych obiektu,

Wskaźnik ogólnej bioróżnorodności Shannona - H

$$
H=-\sum_{i=1}^{S} p_{i} \log _{n} p_{i}
$$

i wskaźnik dominacji Simsona - C

$$
\mathrm{C}=\sum \mathrm{p}_{\mathrm{i}}^{2}
$$

s - liczba gatunków,

$\mathrm{p}_{\mathrm{i}}$ - stosunek liczby osobników i-tego gatunku do całkowitej liczebności wszystkich osobników.

Uzyskane wyniki opracowano statystycznie z wykorzystaniem analizy wariancji, natomiast istotność różnic oszacowano testem Tukeya.

\section{Wyniki i dyskusja / Results and discussion}

Sposób uprawy roli różnicował istotnie liczebność chwastów w łanie jęczmienia jarego (tab. 1). Zaniechanie uprawy płużnej i wykonanie siewu bezpośredniego w odniesieniu do obiektów z uprawą orkową zwiększyło świeżą masę chwastów o ponad 100\%, a ich liczbę o około $60 \%$. Podobne rezultaty uzyskiwali Dzienia i wsp. (1998); Orzech i wsp. (2011); Woźniak (2011) oraz Giemza-Mikoda i wsp. (2012) wskazując na wzrost zachwaszczenia przy stosowaniu uproszczonych technik uprawy roli. Zachwaszczenie jęczmienia według badań Blecharczyka i wsp. (2007) jest uzależnione od systemu uprawy oraz zmianowania. Uprawiając jęczmień w zmianowaniu stwierdzono większą masę chwastów na obiektach z uprawą tradycyjna. Przy jego uprawie w monokulturze zbożowej, większą masą chwastów charakteryzowały się obiekty z siewem bezpośrednim.

Rodzaj przedplonu również w sposób istotny różnicował liczbę i masę chwastów na jednostce powierzchni. $Z$ reguły przy uprawie zbóż w płodozmianie zachwaszczenie jest mniejsze niż przy ich wysiewie w monokulturze (Stevenson i wsp. 1997). W jęczmieniu uprawianym w stanowisku po buraku odnotowano $14 \mathrm{szt} . / \mathrm{m}^{2}$ chwastów, a gdy uprawiano go w stanowisku po kukurydzy zanotowano wzrost o $42 \%$. Natomiast różnica w odniesieniu do masy chwastów w łanie jęczmienia przy jego uprawie po kukurydzy wynosiła $58 \%$ i została potwierdzona statys- 
tycznie. Na zróżnicowanie liczby i powietrznie suchej masy chwastów w łanie zbóż przy różnym przedplonie wskazuje również Woźniak (2004). Autor ten twierdzi również, że zróżnicowanie to może następować pod wpływem sposobu odchwaszczania. Z kolei w badaniach Jastrzębskiej i wsp. (2012) najniższą masę chwastów stwierdzono przy uprawie jęczmienia w stanowisku po roślinach okopowych, natomiast, gdy jęczmień uprawiano w zmianowaniu z 75\% udziałem tego zboża następował wzrost ich masy. Zdaniem Zawiślak (1997) jęczmień uprawiany w płodozmianie po starannie pielęgnowanych okopowych nie wymaga stosowania herbicydów. $\mathrm{Na}$ analizowanych obiektach (tab. 2) w zbiorowisku chwastów była podobna liczba gatunków (uprawa tradycyjna - 11, siew bezpośredni - 10). Na obiektach z orką nie odnotowano występowania Matricaria maritima ssp. inodora, której obecność stwierdzono na obiektach z siewem bezpośrednim. $\mathrm{Z}$ kolei w przypadku obiektów bez uprawy płużnej nie odnotowano występowania takich gatunków, jak: Lycopsis arvensis i Poa annua. W zasiewach szcze- gólnie licznie pojawiły się takie gatunki, jak: Viola arvensis - 33,3\% udziału $\mathrm{w}$ zbiorowisku liczby chwastów z uprawą tradycyjną i $22 \%$ siew bezpośredni, Chenopodium album 10,5\% uprawa tradycyjna i 15,2\% obiekty $\mathrm{z}$ siewem bezpośrednim, Senecio vulgaris odpowiednio 12,7 i 10,2\% oraz Geranium pusillum 7,3 i 11,8\%.

Analizując rodzaj przedplonu dominującym gatunkiem w zbiorowisku był $V$. arvensis zarówno w przypadku uprawy jęczmienia po buraku pastewnym $24 \%$, jak i po kukurydzy 28,6\%. W zasiewach jęczmienia, w stanowisku po kukurydzy obserwowano większy udział takich gatunków chwastów, jak: S. vulgaris, L. arvensis, Echinochloa crus-galli i Brassica napus. Z kolei uprawa jęczmienia w stanowisku po buraku powodowała większy udział w zbiorowisku takich taksonów, jak: Ch. album, G. pusillum, Anthemis arvensis i M. maritima. Spośród gatunków, które występowały w zbiorowisku, kiedy uprawiano jęczmień $\mathrm{w}$ technologii płużnej po buraku pastewnym wyższe wartości wskaźnika obfitości Ra

Tabela 1. Wpływ sposobu uprawy roli i przedplonu na liczbę i świeżą masę chwastów (średnia z lat 2008-2009)

Table 1. Effect of soil tillage system and previous crops on number and fresh weight of weeds (mean from 2008-2009)

\begin{tabular}{l|c|c}
\hline \multicolumn{1}{c|}{$\begin{array}{c}\text { Sposób uprawy roli } \\
\text { Tillage system }\end{array}$} & $\begin{array}{c}\text { Liczba chwastów }\left[\mathrm{szt} . / \mathrm{m}^{2}\right] \\
\text { Number of weeds }\left[\mathrm{pcs} / \mathrm{m}^{2}\right]\end{array}$ & $\begin{array}{c}\text { Masa chwastów }\left[\mathrm{g} / \mathrm{m}^{2}\right] \\
\text { Weed weight }\left[\mathrm{g} / \mathrm{m}^{2}\right]\end{array}$ \\
\hline Tradycyjna - Conventional & 16 & 100,3 \\
Siew bezpośredni - Direct drilling & 26 & 203,0 \\
\hline NIR $(0,05)$ - LSD $(0.05)$ & istotne - significant & 111,6 \\
\hline Przedplon - Previous crop & & istotne - significant \\
Burak pastewny - Fodder beet & 14 & 191,7 \\
Kukurydza - Maize & 20 & istotne - significant \\
\hline NIR $(0,05)$ - LSD $(0.05)$ & istotne - significant &
\end{tabular}

Tabela 2. Wpływ sposobu uprawy roli i przedplonu na procentowy udział poszczególnych gatunków w zachwaszczeniu ogólnym (średnia z lat 2008-2009)

Table 2. Effect of tillage system and previous crop on percentage share of species in total number of weeds (mean from 2008-2009)

\begin{tabular}{l|c|c|c|c}
\hline \multirow{2}{*}{$\begin{array}{c}\text { Gatunki } \\
\text { Species }\end{array}$} & \multicolumn{2}{|c|}{ Sposób uprawy roli - Tillage system } & \multicolumn{2}{c}{ Przedplon - Previous crop } \\
\cline { 2 - 5 } & $\begin{array}{c}\text { tradycyjna } \\
\text { conventional }\end{array}$ & $\begin{array}{c}\text { siew bezpośredni } \\
\text { direct drilling }\end{array}$ & $\begin{array}{c}\text { burak pastewny } \\
\text { fodder beet }\end{array}$ & $\begin{array}{c}\text { kukurydza } \\
\text { maize }\end{array}$ \\
\hline Viola arvensis Murray & 33,3 & 22,0 & 24,0 & 28,6 \\
\hline Senecio vulgaris L. & 12,7 & 10,2 & 3,5 & 16,8 \\
\hline Chenopodium album L. & 10,5 & 15,2 & 19,3 & 8,9 \\
\hline Geranium pusillum Burm. R. ex. L. & 7,3 & 11,8 & 11,4 & 8,9 \\
\hline Lycopsis arvensis L. & 7,3 & - & 2,5 & 5,0 \\
\hline Echinochloa crus-galli (L.) Beauv. & 5,7 & 3,4 & 3,8 & 4,8 \\
\hline Anthemis arvensis L. & 5,1 & 10,0 & 9,5 & 6,8 \\
\hline Brassica napus L. var. oleifera Metzger & 5,1 & 3,4 & 3,8 & 4,3 \\
\hline Polygonum avicurale L. & 4,8 & 4,8 & 4,7 & 4,8 \\
\hline Stellaria media L.) & 2,5 & 3,2 & 5,1 & - \\
\hline Poa annua L. & 2,2 & - & - & 2,3 \\
\hline Matricaria maritima ssp. inodora L. & - & 8,8 & 7,3 & \\
\hline Inne - Other & 11,0 & 7,3 & 5,2 & 3,9 \\
\hline
\end{tabular}


stwierdzono w przypadku $V$. arvensis, A. arvensis, E. crusgalli, B.napus oraz L. arvensis (rys. 1). Obliczone wartości wskaźnika relatywnej obfitości Ra dla gatunków występujących w łanie jęczmienia uprawianego po kukurydzy w technologii siewu bezpośredniego były wyższe dla takich taksonów, jak: $V$. arvensis, Ch. album, $S$. vulgaris, G. pusillum oraz M. maritima (rys. 2).

Przeciętne wartości ( $\mathrm{z}$ dwóch lat badań) wskaźnika bioróżnorodności $(\mathrm{H})$ nie były istotnie zróżnicowane anali- zowanymi czynnikami doświadczenia (rys. 3). Zaznaczyła się jedynie tendencja zróżnicowania wskaźnika bioróżnorodności $(\mathrm{H})$ w wyniku interakcji badanych czynników. Na obiektach uprawianych płużnie zjawisko to występowało w stanowisku po buraku pastewnym, natomiast w technologii siewu bezpośredniego w stanowisku po kukurydzy. Nie stwierdzono również interakcji pomiędzy sposobem uprawy gleby, a zastosowanym rodzajem przedplonu.

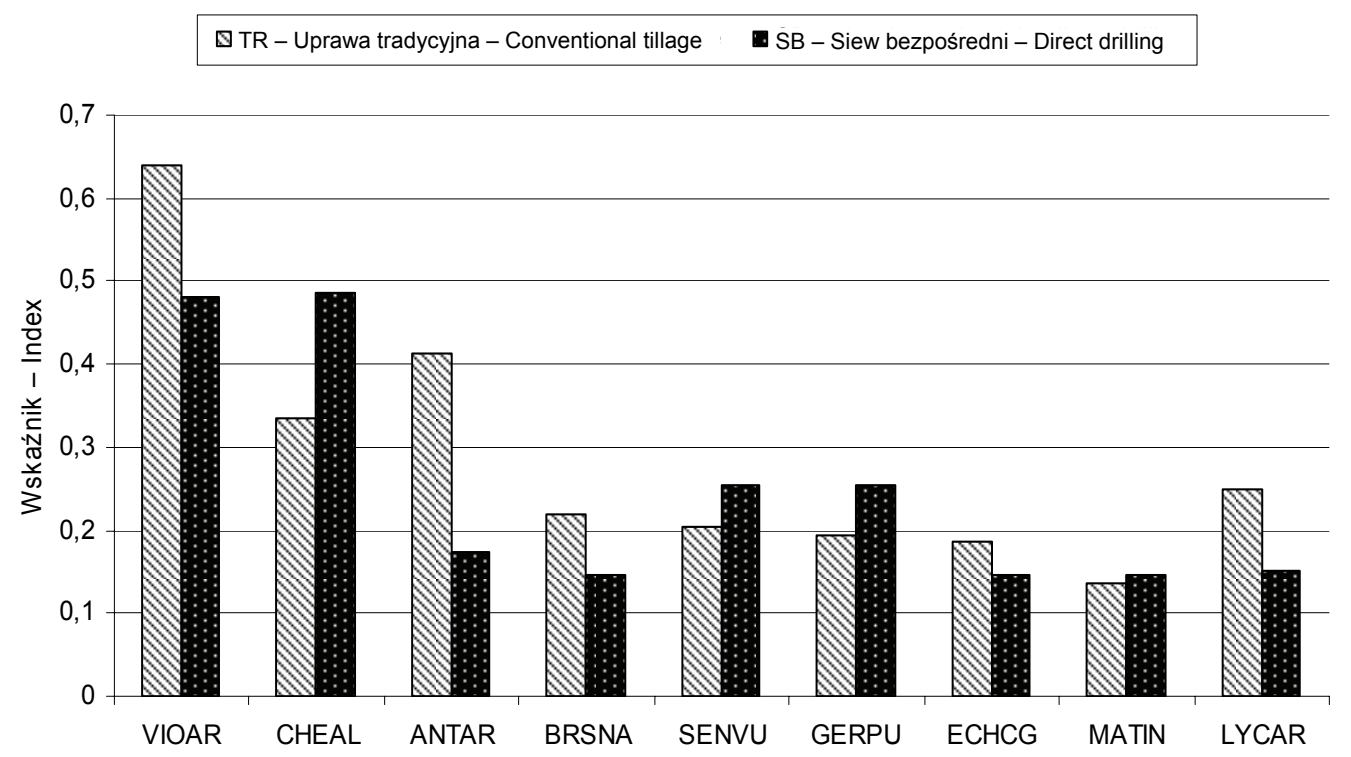

VIOAR - Viola arvensis, CHEAL - Chenopodium album, ANTAR - Anthemis arvensis, BRSNA - Brassica napus, SENVU - Senecio vulgaris, GERPU - Geranium pusillum, ECHCG - Echinochloa crus-galli, MATIN - Matricaria maritima, LYCAR - Lycopsis arvensis

Rys. 1. Obfitość najważniejszych gatunków chwastów występujących w buraku pastewnym, w zależności od sposobu uprawy roli, wyrażona wskaźnikiem Ra

Fig. 1. Abundance of major weed species in fodder beet depending on soil tillage system expressed by Ra index

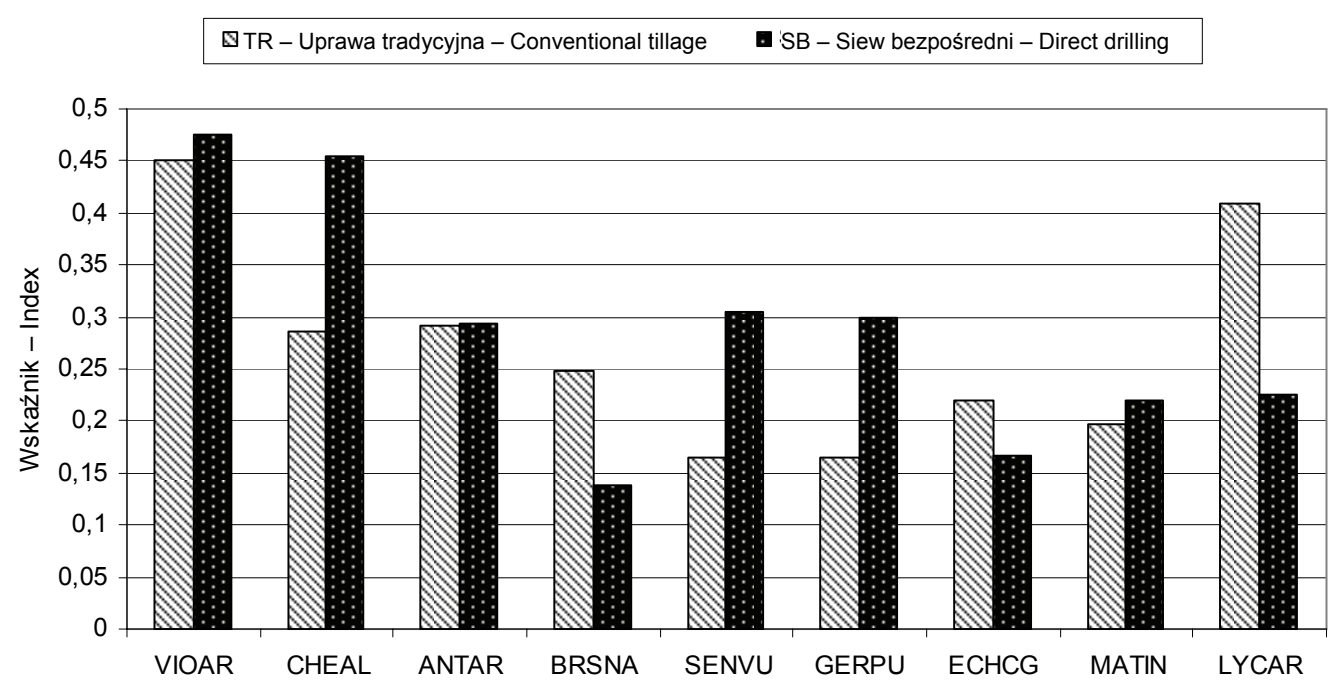

VIOAR - Viola arvensis, CHEAL - Chenopodium album, ANTAR - Anthemis arvensis, BRSNA - Brassica napus, SENVU - Senecio vulgaris, GERPU - Geranium pusillum, ECHCG - Echinochloa crus-galli, MATIN - Matricaria maritima, LYCAR - Lycopsis arvensis

Rys. 2. Obfitość najważniejszych gatunków chwastów występujących w kukurydzy, w zależności od sposobu uprawy roli, wyrażona wskaźnikiem Ra

Fig. 2. Abundance of major weed species in maize depending on soil tillage system expressed by Ra index 


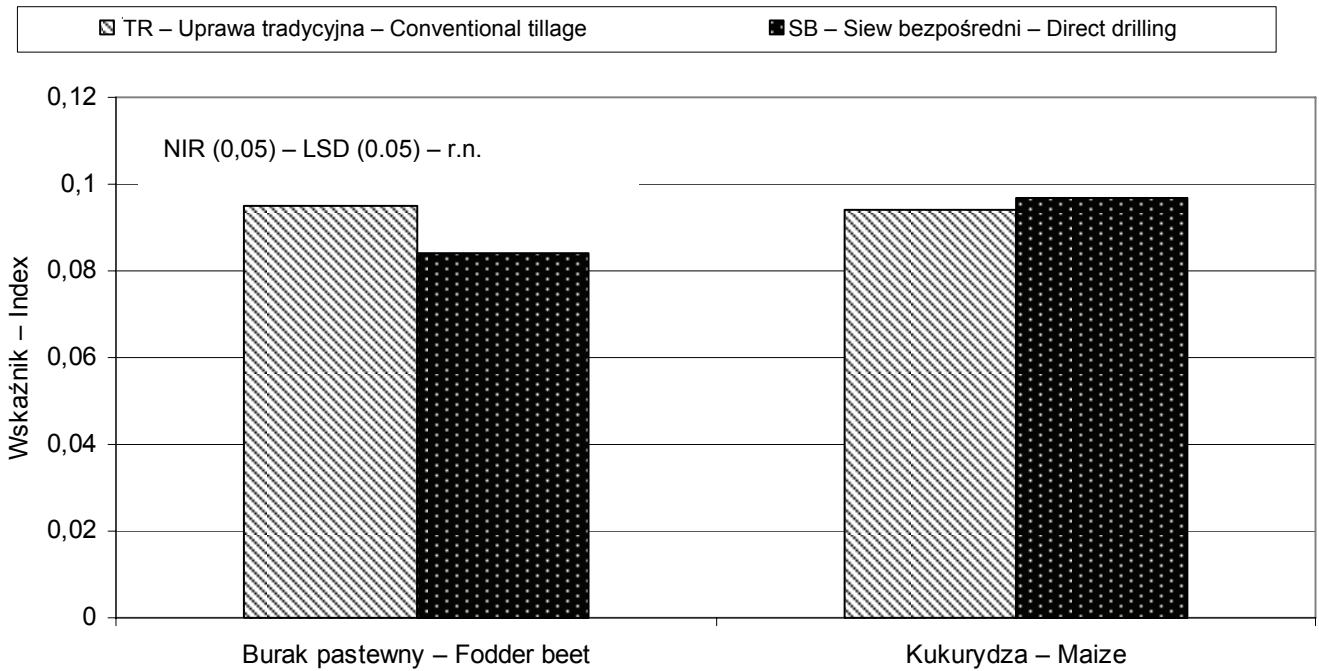

r.n. - różnica nieistotna - not significant difference

Rys. 3. Wartość wskaźnika bioróżnorodności Shannona - H (średnio 2008-2009)

Fig. 3. Value of Shannon's biodiversity index - H (average of years 2008-2009)

\begin{tabular}{|c|c|}
\hline = Burak pastewny-Fodder beet & DKukurydza - Maize \\
\hline $\begin{array}{l}\text { } \overline{T R} \text { - Uprawa tradycyjna - Conventional tillage } \\
\square \mathrm{NIR}(0,05) \text { - LSD }(0.05)\end{array}$ & SB - Siew bezpośredni - Direct drilling \\
\hline
\end{tabular}

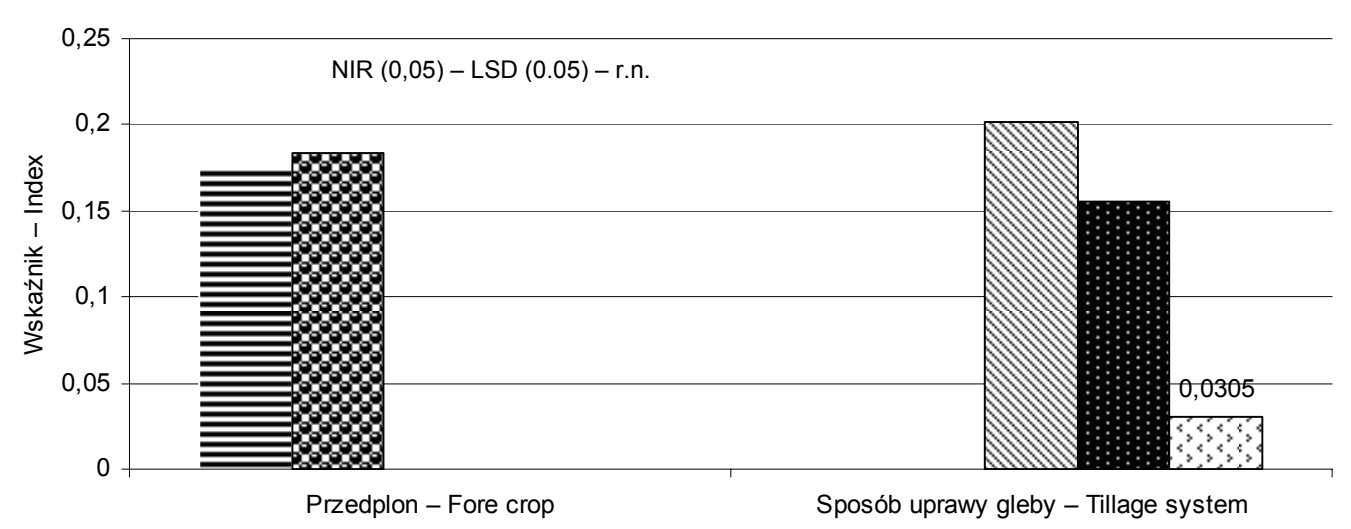

r.n. - różnica nieistotna - not significant difference

Rys. 4. Wartość wskaźnika dominacji - C (średnio 2008-2009)

Fig. 4. Dominance index value - C (average of years 2008-2009)

Przeprowadzone badania nie wykazały istotności wpływu przedplonu na wartość wskaźnika dominacji (C) Simpsona, choć był on wyższy przy uprawie jęczmienia po kukurydzy, niż po buraku. Uwidocznił się natomiast istotny wpływ sposobu uprawy gleby na wyliczone wartości wskaźnika dominacji. Były one wyższe w odniesieniu do zachwaszczenia na obiektach $\mathrm{z}$ uprawą jęczmienia w technologii płużnej (rys. 4), co jest zgodne z rezultatami badań (McCloskey i wsp. 1996; Bilalis i wsp. 2001). W badaniach Wesołowskiej-Janczak i wsp. (2000), a także Hernandeza Plaza i wsp. (2011) nie wykazano istotnego zróżnicowania wartości wskaźników zachwaszczenia przy zróżnicowanych sposobach uprawy gleby. Z kolei Carter i Ivany (2006) donoszą, że po uproszczeniach uprawowych i siewie bezpośrednim wartości wskaźników są podobne, ale przyjmują niższe wartości niż po uprawie tradycyjnej gleby.

\section{Wnioski / Conclusions}

1. Uproszczenia uprawowe (siew bezpośredni w stosunku do tradycyjnej uprawy płużnej) wpłynęły na ponad $100 \%$ wzrost masy chwastów. Podobnie liczebność chwastów była większa na obiektach z siewem bezpośrednim, a wzrost zachwaszczenia w stosunku do tradycyjnej uprawy płużnej wynosił około $60 \%$.

2. Rodzaj przedplonu miał wpływ na liczbę chwastów w łanie jęczmienia jarego. Na obiektach, na których wysiewano go po kukurydzy stwierdzono o $40 \%$ większą liczbę chwastów w odniesieniu do jego uprawy po buraku pastewnym.

3. Wyliczone wartości wskaźnika dominacji (C) były istotnie wyższe przy uprawie jęczmienia w technologii tradycyjnej. 
4. Zastosowane systemy uprawy roli oraz zmianowanie w niewielkim stopniu różnicują wartość wskaźnika bioróżnorodności Shannona $(\mathrm{H})$. Zaznacza się jedynie tendencja do zwiększania jego wartości w przypadku płużnej uprawy jęczmienia po buraku pastewnym oraz siewu bezpośredniego w stanowisku po kukurydzy.

\section{Literatura / References}

Bilalis D., Efthimiadis P., Sidras N. 2001. Effect of three tillage systems on weed flora in a 3-year rotation with four crops. J. Agron. Crop Sci. 186: 135-141.

Blecharczyk A., Małecka I., Dobrzaniecki T., Zawada D. 2007. Wpływ następstwa roślin oraz uprawy roli na zachwaszczenie jęczmienia jarego. [Effect of cropping and tillage systems on weed infestation of spring barley]. Prog. Plant Prot./Post. Ochr. Roślin 47 (3): 52-55.

Carter M.R., Ivany J.A. 2006. Weed seed bank composition under three long-term tillage regimes on a fine sandy loam in Atlantic Canada. Soil Till. Res. 90: 29-38.

Dzienia S., Piskier T., Wereszczaka J., Wrzesińska E. 1998. Wpływ systemów uprawy roli na plonowanie i zachwaszczenie jęczmienia jarego. Folia Univ. Agric. Stetin., Agricultura 69: 33-36.

Ghosheh H., Al-Hajaj N. 2004. Impact of soil tillage and crop rotation on barley (Hordeum vulgare) and weeds in a semi-arid environment. J. Agron. Crop Sci. 190: 374-380.

Giemza-Mikoda M., Zimny L., Wacławowicz R. 2012. Wpływ systemów uprawy na zachwaszczenie jęczmienia jarego. [The influence of cultivation systems on weed infestation in spring barley]. Prog. Plant Prot./Post. Ochr. Roślin 52 (2): 283-286.

Hernandez Plaza E., Kozak M., Navarrete L., Gonzalez-Andujar J.L. 2011. Tillage system did not affect weed diversity in a 23-year experiment in Mediterranean dryland. Agriculture, Ecosystems Environment 140: 102-105.

Jastrzębska M., Wanic M., Kostrzewska M.K., Treder K., Nowicki J. 2012. An attempt to use functional diversity indices for the assessment of weed communities. Acta Agrobot. 65 (1): 129-140.

Kraska P., Pałys E. 2006. Plonowanie jęczmienia jarego uprawianego w warunkach zróżnicowanych poziomów agrotechniki. Fragm. Agron. 23 (2): 299-308.

Małecka I., Blecharczyk A., Sawinska Z., Dobrzaniecki T. 2012. The effect of various long-term tillage systems on soil properties and spring barley field. Turk. J. Agric. For. 36: 217-226.

McCloskey M., Firbank L.G., Watkinson A.R., Webb D.J. 1996. The dynamics of experimental arable weed communities under different management practices. J. Veg. Sci. 7: 779-808.

Orzech K., Rychcik B., Stępień A. 2011. Wpływ sposobów uprawy roli na zachwaszczenie i plonowanie jęczmienia jarego. Fragm. Agron. 28 (2): 63-79.

Schillinger W., Cook R., Papendick R. 1999. Increased dryland cropping intensity with no-till barley. Agron. J. 91: 744-752.

Starczewski J., Czarnocki Sz. 2004. Sposób uprawy roli a zachwaszczenie i plonowanie pszenżyta. Acta Sci. Pol. Agricultura 3 (2): $69-76$.

Stevenson F.C., Légere A., Simard R.R., Angers D.A., Pageau D., Lafond J. 1997. Weed species diversity in spring barley varies with crop rotation and tillage, but not with nutrient source. Weed Sci. 45: 798-806.

Topham P.B., Lawson H.M. 1982. Measurement of weed species diversity in crop/weed competition studies. Wed Res. 22: $285-293$.

Tørresen K.S., Skuterud R., Tandsaether H.J., Hagemo M.B. 2003. Long-term experiments with reduced tillage in spring cereals. I. Effects on weed flora, weed seedbank and grain yield. Crop Prot. 22: 185-200.

Wesołowska-Janczak M., Kubik-Komar A., Jędruszczak A. 2000. Zastosowanie współczynników bioróżnorodności do badania wpływu sposobu uprawy i dawki herbicydów na zbiorowisko chwastów. Polskie Towarzystwo Biometryczne, Lublin, Colloqium biometryczne 30: 333-344.

Woźniak A. 2004. Następczy wpływ jęczmienia jarego uprawianego w zmianowaniu i monokulturze na zachwaszczenie pszenicy ozimej. Ann. UMCS, Sec. E, 59 (3): 1029-1036.

Woźniak A. 2011. Weed infestation of spring wheat crop under the conditions of plough and ploughless tillage. Acta Agrobot. 64 (3): $133-140$.

Zawiślak K. 1997. Regulacyjna funkcja płodozmianu wobec chwastów w agrofitocenozach zbóż. Acta Acad. Agricult. Tech. Olsz., Agricultura 64: 81-99. 